\title{
Endemic Rice Pulu' Mandoti Supports the Economy and Food Security at Salukanan Community During Covid-19 Global Pandemic Crisis
}

\author{
Abdul Karim \\ Doctoral Student in Economic Program Universitas Negeri Makassar \\ Indonesia STIE AMKOP Makassar, Indonesia
}

\begin{abstract}
Salukanan Village is one of the villages in the Enrekang Regency, precisely in the Baraka District. The area of Salukanan Village has an area of \pm 1716 $\mathrm{KM}^{4}$ and is inhabited by 1,232 people. Its population depends on the agricultural sector. A well-known agricultural product from Salukanan Village is Pulu' Mandoti (glutinous rice). Various studies have been conducted by several researchers and the conclusion is that Pulu 'Mandoti can only grow with a distinctive aroma in the rice fields of Salukanan Village. Currently, Pulu' Mandoti glutinous rice is the most expensive rice in Indonesia because the price reaches IDR. 55,000 kilograms.
\end{abstract}

Keywords:- Pulu 'Mandoti, Economic Support, Food Security, Covid-19.

\section{INTRODUCTION}

Enrekang Regency is one of the Second Level Regions in the province of South Sulawesi, Indonesia. The district capital is located in Enrekang City $\pm 236 \mathrm{~km}$ north of Makassar. Administratively it consists of 12 definitive sub-districts, there are 129 sub-districts / villages, namely 17 wards and 112 villages, with an area of $1,786.01 \mathrm{~km}^{2}$. Located at coordinates between $3^{\circ} 14^{\circ} 36^{\circ}$ to $03^{\circ} 50$ '00 "south latitude and $119^{\circ} 40^{\prime} 3^{\prime \prime}$ to $120^{\circ} 06$ "33" east longitude, (BPS Enrekang, 2018).

The boundaries of this regency are in the north bordering Tana Toraja Regency, south by Luwu Regency, east by Sidrap Regency and west by Pinrang Regency. This district generally has a varied topographical area in the form of hills, mountains, valleys, and rivers with an altitude of 47 - 3,293 $\mathrm{m}$ above sea level and has no coastal area. In general, the topography of the area is dominated by hills/mountains, which is around $84.96 \%$ of the total area of the Enrekang Regency, while the flat area is only $15.04 \%$. The season that occurs in Enrekang Regency is almost the same as the season in other areas in South Sulawesi Province, namely the rainy season and the dry season where the rainy season occurs in November - July while the dry season occurs in August - October.

\section{SALUKANAN VILLAGE AS AN ETHNIC AGRICULTURAL AREA IN ENREKANG REGENCY}

From the economic activity, it appears that there are significant differences between the two regions. In general, trade and industrial activities are in the Kawasan Barat Enrekang (KBE) area. In addition, service industries such as transportation, telecommunications, hotels, restaurants, banking, agricultural processing industry trade have the potential to be developed in the region. Meanwhile, Kawasan Timur Enrekang (KTE), which has been considered relatively left behind when viewed from the availability of socio-economic facilities and infrastructure, is very adequate in terms of natural resource potential, so it is very potential for agricultural development, namely food crop agriculture/horticulture, plantations, and community forest development. (Hasmah, 2020).

The Eastern Region of Enrekang, which has a large area with various potentials, provides opportunities for the development of food crops and horticulture as well as plantation and forestry crops. The limited access of Kawasan Timur Enrekang (KTE) to the Western Region of Enrekang indicates the need for policies or strategic steps that allow the two regions to work together towards achieving the regional vision and mission.

The residents of Salukanan Village mostly work as farmers, some of the famous agricultural products from this village are pulu' mandoti rice (red glutinous rice) with a very distinctive and strong fragrance, besides that this village also produces salak fruit, coffee, pepper, and vegetables. vegetables. Pulu' Mandoti rice is a type of red glutinous rice that can only grow in Salukanan Village, so it can be said that this rice is an endemic plant in Salukanan Village, Baraka District, Enrekang Regency, the Pulu Mandoti glutinous rice plant can grow elsewhere but will not produce rice. The same quality as Pulu' Mandoti rice produced from the land of Salukanan Village where in other areas glutinous rice is produced which is red but does not produce rice that has a strong distinctive smell. Pulu Mandoti rice is only processed into Songkolo (rice made from glutinous rice) and only served at certain times such as at weddings, family gatherings or other events, so that cultivation is limited in number (Aktsar Roskiana Ahmad, 2016). 


\section{AGRICULTURAL SECTOR IN SUPPORTING REGIONAL ECONOMIC GROWTH IN ENREKANG REGENCY}

Enrekang Regency area is 1,786.01 $\mathrm{Km}^{2}$, Civil Servants 4,437 people in 2019, population 206,387 people, the Year 2019. Enrekang Regency has a harvest area of 1,093 ha of chilies spread over 12 sub-districts. 5 Business Fields with the Largest Contribution of Enrekang Regency Gross Regional Domestic Product 2019, namely:

$>$ Agriculture, forestry, fisheries $=38.51 \%$

$>$ Processing Industry $=14.02 \%$

$>$ Construction $=12.96 \%$

$>$ Wholesale and retail trade; car and motorcycle repair $=$ $8.09 \%$

$>$ Government administration, Defense and Social security $=7.48 \%$

The potential for rice plants in Enrekang Regency is very minimal. Even so, the Enrekang Agricultural Service is still trying to expand the land to increase production next year. Rice production only reaches 53,000 tons per year for a harvest area of approximately 11,000 hectares this year. Most of the production comes from the southern region of the Enrekang Regency, such as Cendana and Maiwa Districts. The planted area only reaches 10,096 hectares. The land area increased to 13013 hectares in 2016. Recently, the district government succeeded in conducting trials of these rice seeds in two villages, namely Salo Dua Village and Patondon Salu in Maiwa District. Each only uses 1 hectare of community rice fields. The result is quite satisfying because it can boost production from 5 tons to 9 tons per hectare, (Aktsar Roskiana Ahmad, dkk. 2016)

Pulu 'Mandoti, one of the rare local types of sticky rice. It can only grow in mountainous areas with an altitude of 700 above sea level, Salukanan Village, Baraka District, about $60 \mathrm{~km}$ from Enrekang City, the capital of Enrekang Regency, South Sulawesi. This glutinous rice is one of the most expensive rice among all types of sticky rice in Indonesia because the price per $\mathrm{kg}$ reaches IDR. 55,000. Salukanan Village has 5 hamlets as the producer of Pulu 'Mandoti, namely Dusun Gandeng, Dusun Piawan, Dusun Matarin, Dusun Tantido, and Dusun. One liter of Pulu Mandoti when mixed with one sack of about 40 liters of ordinary rice, is able to make the whole ordinary rice smell good, causing people's appetite to eat it.

Another uniqueness of Pulu 'Mandoti is because for a long time many people have taken the seeds to be planted or developed outside the Salukanan Village area. However, the result was taken out of the area of Salukanan Village, the smell was not the same as that of the Salukanan Village. There have been several other villages neighboring Salukanan Village trying to plant them but the results are not the same as the aroma in Salukanan Village and some even cannot grow.

\section{PULU' MANDOTI IS THE FOOD STOCK OF THE SALUKANAN VILLAGE COMMUNITY DURING THE GLOBAL COVID-19 PANDEMIC}

Salukanan village itself has 312 hectares of rice fields, but only about 250 hectares can be planted with Pulu' Mandoti with a harvest period once a year. Pulu' Mandoti farmers took to the rice fields in March to plant and only harvested them 6 months after planting. Approximately 500 tons per year. The very high selling price of IDR. 55,000 per liter in 2019 and reaches a price of IDR. 60,000 in 2020. This high price is comparable to the cultivation time which reaches six months from planting to harvest. The amount of production is apparently not enough to meet market needs in Baraka District. Concrete efforts need to be made to develop these prospects, therefore it is necessary to formulate a strategy that must be taken to develop the prospect of Pulu 'Mandoti flavored rice to make it more promising and profitable, (Kompasiana, 2012).

During the "Covid-19" Global Pandemic Crisis, the people of Salukanan Village made Pulu 'Mandoti their staple food because people assumed that Pulu' Mandoti could last a long time to endure hunger compared to other rice. In addition, paddy from Pulu' Mandoti can be stored for up to 5 years in the barn. Apart from providing food security for rural communities, Pulu 'Mandoti can also support economic improvement for the people in Salukanan Village because the price is quite expensive compared to any other rice (Karim, A. 2020).

In addition, Pulu' Mandoti Local Rice has proposed IPR Geographical Indication (GI) as a sign indicating the area of origin of a product and/or product which is due to geographical environmental factors including natural factors, human factors, or a combination of these two factors gives reputation, quality. , and certain characteristics of the goods and/or products produced. GI is owned by people who produce region-specific products, ownership of GI cannot be traded, and GI is valid as long as the specificity of the product is still maintained and GI protection is internationally recognized and listed in the Trip's Agreement and WTO.

As for the benefits of Geographical Indications (GI), namely the prevention of transfer of ownership of product use rights from local communities to other parties. Maximizing the added value of products for the local community. Provides protection from product counterfeiting. Increased marketing of typical products. Increasing the provision of employment opportunities. Supporting the development of agro-tourism. Ensuring business continuity; Strengthening the regional economy; Accelerate regional development. Improve community welfare. Guarantee the quality of the product. Provide legal guarantees for consumers if the product is not in accordance with the expected standards (Bustanul, 2017). 


\section{CONCLUSION}

During the "Covid-19" Global Pandemic Crisis, the people of Salukanan Village, amounting to 1,232 people, have prepared food security for the community and maintain the availability of Pulu 'Mandoti as an ingredient in meeting their daily basic needs. Apart from meeting basic needs, Pulu 'Mandoti is also quite economically valuable with prices reaching IDR. 60,000 per liter, also because it is supported by the factor of the Holy Month of Ramadan. Where every fasting month as it is today, there is always a significant increase from people outside the Salukanan Village area.

\section{REFERENCES}

[1]. Ahmad, F., Ahmad, I, \& M. S., Khan, (2005). Indole Acetic Acid production by the indigenous Isolates of Azotobacter and Flourescent pseudomonas in the Presence and Absence of Tryptophan. India : Departement of Agricultural Microbiology, Faculty of Agricultural Sciences, Aligarh Muslim University. Vol.29, 29-34.

[2]. Aktsar Roskiana Ahmad, Abd. Malik, Zakir Sabara HW (2016). Menciptakan Desa Mandiri Kesehatan di Desa Salukanan Kecamatan Baraka Kabupaten Enrekang. Jurnal Balireso Vol. 1, No. 1, Januari 2016. page. $70-82$.

[3]. Arman. (2017). Strategi Pengembangan Beras Beraroma "Pulu Mandoti" Berbasis Agribisnis di Kabupaten Enrekang. Universitas Muhammadiyah Parepare. Parepare.

[4]. Arif, Daryanto. (2004). Penguatan Kelembagaan Sosial Ekomoni Masyarakat Sebagai Modal Sosial Pembangunan. Central Library of Bogor Agricultural University, Bogor.

[5]. Asriati, N dan Y. Bahari. (2010). Pengendalian Sosial Berbasis Modal Sosial Lokal pada Masyarakat di Kalimantan Barat. MIMBAR, Vol. XXVI, No. 2 (Desember 2010): 147-158.

[6]. Bacon, C. W., A. E. Glenn, and D. M. Hinton. (2002). Isolation In Planta Detection and Culture of Endophytic and Fungi. In: C. J. Hurst, R. L. Crawford, M. J. Mcineraey, G. R. Knudsen and L. D Stetzenbach (Eds). Manual of Environmental.

[7]. Beattie, G. A., (2002). Leaf Surface Waxes and the Process of Leaf Colonization by Microorganisms. In : Lindow SE, editor. Phyllosphere Microbiology. Minnesota: APS Pr. page: 3-26.

[8]. Busthanul, Nurbaya. (2017). Modal sosial: peran, unsur, dan pengaruhnya Terhadap usaha tani padi "pulu mandoti" Di enrekang. Jurusan Sosial Ekonomi Pertanian Fakultas Pertanian, Universitas Hasanuddin

[9]. BPS Kabupaten Enrekang. (2018). Kondisi Umum Wilayah Kabupaten Enrekang. https://enrekangkab.bps.go.id.
[10]. Compant, S., B. Duffy, J. Nowak, C. Clement, and E. A. Barka, (2005). Use of Plant Growth- Promoting for Biocontrol of Plant Disease: Principles, Mechanisms of Action, and Future Prospects. Appl. Environ. Microbiol. 71, 4951-4959.

[11]. Hasmah. (2020). Makanan Tradisional Pulu Mandoti Kabupaten Enrekang. Journal Walajusi, Vol. 11, No. 1 Juni 2020. page. 171-181.

[12]. Irmayani, dkk. (2018). Strategi Pengembangan Beras Beraroma "Pulu Mandoti" Berbasis Agribisnis di Kabupaten Enrekang. Prosiding Konferensi Nasional Ke- 7 Asosiasi Program Pascasarjana Perguruan Tinggi Muhammadiyah Aisyiyah (APPPTMA). page. 88-94.

[13]. Karim, A. (2016). MANAJEMEN KEBIJAKAN DESENTRALISASI FISKAL DALAM PENINGKATAN PENDAPATAN ASLI DAERAH KABUPATEN ENREKANG. https://www.academia.edu/42545058.

[14]. Karim, A. (2017). MANAJEMEN PENGELOLAAN PROGRAM PEMBERDAYAAN PENANGGULANGAN KEMISKINAN MELALUI KUBE DI KABUPATEN ENREKANG. https://www.academia.edu/42545341.

[15]. Karim, A. (2017). MANAJEMEN PENGELOLAAN BANTUAN PERALATAN MESIN KEPADA PELAKU USAHA KECIL DAN MENENGAH DI KABUPATEN https://www.academia.edu/42545341.

ENREKANG.

[16]. Karim, A. (2019). Peningkatan Ekonomi Desa Melalui Badan Usaha Milik Desa (BUMDes). Nas Media Pustaka, Makassar.

[17]. Karim. A. (2019). The Effect of" Axis Hits Bonus" Version Tagline Advertising and Ambassador Brand Against Axis Cards Awareness. In First International Conference on Materials Engineering and Management-Management Section (ICMEMm 2018). Atlantis Press.

[18]. Kompasiana. (2012). Pulu Mandoti, Beras Ketan Termahal di Indonesia. http://www.kompasiana.com. Diakses pada tanggal 28 Agustus 2020.

[19]. Latif, Musfirah. (2016). Prospek Pengembangan Beras beras beraroma "pulu mandoti" (Kasus Pada Usahatani).

[20]. Maas, Linda T., Sirojuzilam, Erlina, and Badaruddin. (2015). The Effect of Social Capital on Governance and Sustainable Livelihood of Coastal City Community Medan. Procedia - Social and Behavioral Sciences 211 (2015).

[21]. Mangkuprawira, Sjarif. 2010. Strategi Peningkatan Kapasitas Modal Sosial dan Kualitas Sumberdaya Manusia Pendamping Pembangunan Pertanian. Forum Peneliti Agro- Ekonomi, Vol. 28 No. 1 Juli 2010: 1934.

[22]. Sahabuddin, R. (2016). Development of business values and behaviours: Takalar district, South Sulawesi (Indonesia) case study. Актуальні проблеми економіки, (2), 440-449. 
[23]. Sahabuddin, R. (2018). Effect of entrepreneurship commitment to self-efficacy through intention of entrepreneurship and competence. International Journal of Business and Management Science, 8(1), 67-81.

[24]. Sahabuddin, R. (2013). Analisis Efikasi Diri dan Komitmen Berwirausaha Serta Dampaknya Pada Kinerja Usaha Rumput Laut Skala Kecil di Kabupaten Jeneponto. Economix, 1(1).

[25]. Sahabuddin, R. The Entrepreneurship Characteristics in Relation to Improve the Performance of the SmallScale Seaweed Entrepreneurs.

[26]. Sahabuddin, R., \& Thaha, S. (2018). EFFECT OF VISUAL LEARNING STYLE AND SCHOOL CLIMATE ON STUDENTS'ACHIEVEMENT OF LEARNING ENTREPRENEURSHIP AT SMKN 1 PALANGGA. Journal of Entrepreneurship Education, 21(3), 1-13.

[27]. Sahabuddin, R. (2019). PENGARUH ROLE OVERLOAD TERHADAP KINERJA PEGAWAI PADA KANTOR BADAN KEPEGAWAIAN DAN DIKLAT DAERAH KABUPATEN MAMUJU TENGAH (Studi Kasus Seleksi Berkas CPNS Kabupaten Mamuju Tengah Tahun 2014). Economix, 4(1). 